\title{
Pharmaceuticals and personal care products as emerging micropollutants in Brazilian surface waters: a preliminary snapshot on environmental contamination and risks
}

\author{
Fernando Fabriz Sodré ${ }^{1+(\mathbb{D})}$, Priscila Mendonça Dutra ${ }^{1}$, Viviane Portela dos Santos ${ }^{1(i)}$ \\ 1 University of Brasília (UnB), Institute of Chemistry, Darcy Ribeiro Campus, Brasília, Distrito Federal, Brazil \\ +Corresponding author: Fernando Fabriz Sodré, e-mail address: ffsodre@unb.br
}

\section{ARTICLE INFO}

Article history:

Received: February, 15, 2018

Accepted: April 23, 2018

Published: June 28, 2018
Keywords:
1. emerging micropollutants
2. Brazilian waters
3. prioritization
4. risk assessment
5. aquatic life

ABSTRACT: This work aimed to present a preliminary snapshot on the contamination and risks of Brazilian surface waters concerning the presence of hormones, pharmaceuticals and personal care products. Data gathered in the literature for Measured Environmental Concentrations (MEC) in Brazilian surface waters were compared with the most restrictive Predicted No-Effect Concentration (PNEC) available in the literature. A risk assessment was performed revealing that hormones, antibiotics drugs and triclosan should be prioritized to subsidize the generation of water quality standards to protect aquatic life.

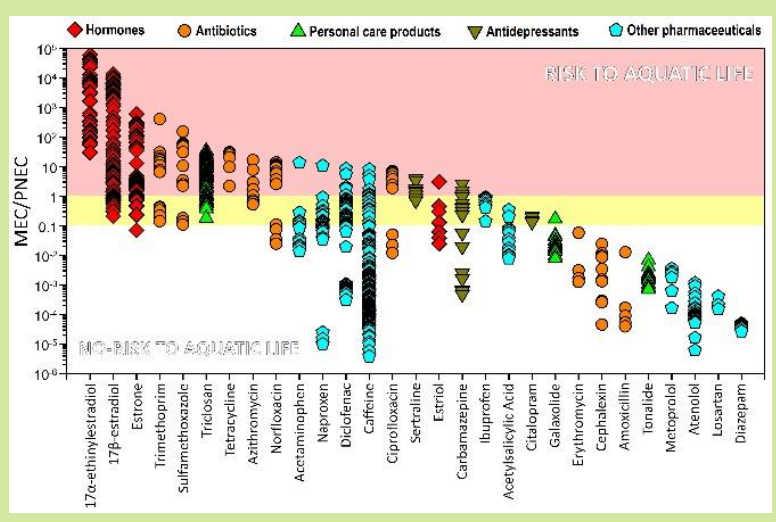

organisms from different trophic levels. For most micropollutants, legislated or not, restrictive criteria have been reported to protect aquatic life, since the protection targets are organisms extremely sensitives to changes in water quality caused by the input of exogenous substances, even at trace concentrations ${ }^{4,5}$.

There are many strategies described in the literature to assess environmental risks of chemicals $^{6-8}$. One of them, as well as the simplest, is based on the comparison of predicted or measured environmental concentrations with predicted no-effect concentration (PNEC) for a given substance ${ }^{9,10}$. The PNEC can be described as the concentration limit which harmful effects on organisms will most likely not occur. For aquatic systems, a PNEC should be derived that, if not exceeded, ensures an overall protection of the 
environment ${ }^{11}$. In the literature, as well as in many reports produced by environmental organizations, several approaches to derive PNEC are described. Most of them are based on a primordial data, mainly obtained from acute or chronic toxicity tests. Standard acute toxicity tests, based on shortterm exposure, are commonly expressed as $\mathrm{EC}_{50}$ or $\mathrm{LC}_{50}$, i.e., the concentration required to cause short-term effects or to kill, respectively, half the organisms of a tested population after a specified exposure time. On the other hand, long-term exposure tests provide toxicity data related to the lowest observable effect concentrations (LOEC) or to no-observable effect concentrations (NOEC).

For some emerging micropollutants, data from both short and long-term toxicity tests can be assessed. However, for other substances, only acute toxicity data may be available. Considering the availability of toxicological data, some extrapolation concerning the aquatic environment has to be done to represent the whole ecosystem sensitivity. Under these circumstances, assessment factors (AF) are used to derive PNEC as follows:

$$
P N E C=\frac{\text { Toxicological data }}{A F}
$$

Both acute $\left(\mathrm{EC}_{50}\right.$ or $\left.\mathrm{LC}_{50}\right)$ and chronic (LOEC or NOEC) toxicological data, derived from singlespecies toxicity tests, are used in the literature to calculate PNEC for aquatic systems. In this case, the lowest figures for these tests, representing the worst-case scenario, are commonly be used. The use of AF was advocate to establish a concentration below which adverse effects will most likely not occur. The magnitude of AF is inversely proportional to the amount and quality of toxicological data available. For example, according to the European Commission technical guidelines $^{11,12}$ an $\mathrm{AF}$ of 1000 is often used when at least one short-term data is available for one of the three organisms representing different aquatic trophic levels, i.e., a fish, a microcrustacean (generally Daphnia), and an alga. When one longterm NOEC data for either fish or Daphnia is available, an AF of 100 or 50 is used. Assessment factors varying from 1 to 10 are used as more longterm NOECs from two to three trophic levels are available. When species sensitivity distribution (SSD) for multi-species data is available the AF must be reviewed on a case by case basis. The same approach is used when field or model ecosystems data are assessed. For the latter approach, modeling software such as QSAR or ECOSAR, based on structure activity relationships (SAR), generate PNECs assuming a common mode of action (narcosis) and may be useful to identify links between micropollutant groups and environmental toxicity ${ }^{6,13}$.

In the literature, risk assessment using PNECs are commonly investigated by the risk quotient (RQ) calculated between the predicted environmental concentration (PEC) and PNEC $^{6,9,14}$. When available, measured environmental concentrations (MEC) reported in the literature may also be used (Equation 2), but in most cases MEC data are scarce for a meaningful analysis?

$$
R Q=\frac{P E C \text { or } M E C}{P N E C}
$$

The predicted concentration of a micropollutant in surface waters can be calculated using information such as the amount of the target substance used per year, the removal efficiency in wastewater treatment plants (WWTP), the volume of wastewater entering a WWTP for a given period, a dilution factor in the environment, amid others ${ }^{15,16}$. Simple PEC calculation may assume that the amount used/consumed is equally distributed over the year, the target substance is used/consumed throughout the region investigated (city, hydrographic basin, country, etc.), it is constantly diluted in the environment without metabolization, transformation, sorption, etc. On the other hand, as pointed out by de Bruijn et al. ${ }^{11}$, data on measured levels provides useful information regarding specific steps of the exposure assessment, such as background levels, concentration ranges and distribution. Also, although measured data present uncertainties associated with temporal and spatial variations, the concentration range may reflect different patterns observed during manufacturing or use of the target substances that are not considered in the modelling procedures. In summary, both PEC and MEC data are important for risk assessment complementing each other during the analysis.

In 2009, Souza et al. ${ }^{17}$ carried out an environmental risk assessment of antibiotics using PEC estimates for 21 substances in Brazil. Consumption data was assessed from reports of an intensive care unit and from hospital pharmacies of the city of Curitiba. One can consider that the most challenging aspect in order to calculate PEC values for pharmaceuticals and personal care 
products in Brazil is the assessment of consumption data. Baldoni et al..$^{18}$ reviewed 620 pharmacoepidemiologic studies produced in Brazil and observed that forms and interviews were frequently used as the main source instead of secondary sources such as prescription data and electronic databases. Locatelli et al. ${ }^{19}$ investigated environmental concentrations for the eight most consumed antibiotics in Brazil according to data obtained from the National Health Surveillance Agency (ANVISA). However, as pointed out by the authors, there is a large number of pharmacies and drugstores selling controlled drugs without prescription throughout the country making the available data uncertain.

In the face of the problems surrounding data gathering for PEC calculations, this work aimed to provide a snapshot on the environmental contamination and risks of pharmaceuticals and personal care products in Brazil, based on the few data available for MEC in surface waters throughout the country. Therefore, our intention is not to perform a complete risk assessment of emerging micropollutants, but rather to provide a scenario consistent with the contamination of Brazilian waters considering the concentration ranges of the most investigated substances as well as their possible risks to the aquatic life.

\section{Experimental}

The most restrictive PNEC values reported in the literature, at the best of our knowledge were selected. In some cases, PNECs were estimated in this work using assessment factors suggested by the European Commission ${ }^{11}$ as well as toxicological data available elsewhere ${ }^{20-24}$. Table 1 shows a list of the most commonly investigated emergent micropollutants in Brazil and PNEC values obtained in the literature or estimated in the present work.

Table 1. Substances selected in this work and their respective PNEC values.

\begin{tabular}{|c|c|c|c|c|}
\hline Main group & Substance & $\begin{array}{l}\text { PNEC } \\
\text { (ng/L) }\end{array}$ & PNEC Calculation & Reference \\
\hline \multirow[t]{4}{*}{ Hormone } & Estrone & 3 & NOEC and $\mathrm{LOEC} ; \mathrm{AF}=5$ & 25 \\
\hline & $17 \beta$-estradiol & 1 & LOEC; $\mathrm{AF}=10$ & 25 \\
\hline & Estriol & 60 & Vitellogenin assay; $\mathrm{AF}=10$ & 26 \\
\hline & $17 \alpha$-ethinylestradiol & 0.1 & NOEC e LOEC; AF=5 & 25 \\
\hline \multirow[t]{10}{*}{ Antibiotic } & Amoxicillin & 100000 & NOEC $; \mathrm{AF}=10$ & 14 \\
\hline & Azithromycin & 19 & Derived from $\mathrm{EC}_{50}{ }^{20} ; \mathrm{AF}=1000$ & This work \\
\hline & Cephalexin & 100000 & NOEC; $A F=10$ & 14 \\
\hline & Ciprofloxacin & 50 & Derived from $\mathrm{NOEC}^{21} ; \mathrm{AF}=100$ & This work \\
\hline & Erythromycin & 27530 & $\mathrm{EC}_{50} ; \mathrm{AF}=1000$ & 27 \\
\hline & Norfloxacin & 20 & Derived from $\mathrm{NOEC}^{21} ; \mathrm{AF}=100$ & This work \\
\hline & Sulfamethoxazole & 10 & Derived from $\mathrm{NOEC}^{21} ; \mathrm{AF}=100$ & This work \\
\hline & Oxytetracycline & 230 & ECOSAR Database & 15 \\
\hline & Tetracycline & 5 & Derived from NOEC ${ }^{21} ; \mathrm{AF}=100$ & This work \\
\hline & Trimethoprim & 16 & Derived from $\mathrm{NOEC}^{21} ; \mathrm{AF}=100$ & This work \\
\hline \multirow{5}{*}{$\begin{array}{c}\text { Anti- } \\
\text { inflammatory }\end{array}$} & Acetylsalicylic acid & 61000 & Derived from $\mathrm{EC}_{50} ; \mathrm{AF}=100$ & 16 \\
\hline & Diclofenac & 1000 & Derived from $\mathrm{NOEC}^{22} ; \mathrm{AF}=100$ & This work \\
\hline & Ibuprofen & 2300 & Derived from $\mathrm{EC}_{50}{ }^{20} ; \mathrm{AF}=1000$ & This work \\
\hline & Naproxen & 2000 & Derived from $\mathrm{NOEC}^{23} ; \mathrm{AF}=10$ & This work \\
\hline & Acetaminophen & 1000 & Derived from $\mathrm{NOEC}^{23} ; \mathrm{AF}=10$ & This work \\
\hline \multirow[t]{3}{*}{ Antidepressant } & Carbamazepine & 250 & $\mathrm{NOEC} ; \mathrm{AF}=10$ & 28 \\
\hline & Citalopram & 360 & ECOSAR Database & 10,29 \\
\hline & Sertraline & 43 & Derived from $\mathrm{EC}_{50} ; \mathrm{AF}=1000$ & 30 \\
\hline Anthelmintic & Mebendazole & 98000 & Derived from $\mathrm{LC}_{50}{ }^{24} ; \mathrm{AF}=1000$. & This work \\
\hline Anxiolytic & Diazepam & 14100 & $\mathrm{EC}_{50} ; \mathrm{AF}=1000$ & 16 \\
\hline \multirow[t]{4}{*}{ Beta blocker } & Atenolol & 77700 & ECOSAR Database & 15 \\
\hline & Metoprolol & 7900 & $\mathrm{EC}_{50} ; \mathrm{AF}=1000$ & 31 \\
\hline & Propranolol & 10 & $\mathrm{NOEC} ; \mathrm{AF}=50$ & 22 \\
\hline & Losartan & 78000 & $\mathrm{NOEC} ; \mathrm{AF}=10$ & 32 \\
\hline Stimulant & Caffeine & 5200 & NOEC; $\mathrm{AF}=100$ & 28 \\
\hline \multirow{3}{*}{$\begin{array}{l}\text { Personal care } \\
\text { product }\end{array}$} & Triclosan & 12 & Derived from $\mathrm{EC}_{50}{ }^{20} ; \mathrm{AF}=1000$ & This work \\
\hline & Galaxolide & 310 & ECOSAR Database & 33 \\
\hline & Tonalide & 4000 & NOEC; $A F=100$ & 34 \\
\hline
\end{tabular}


Details on the toxicological assays used to estimate the PNEC values portrayed in Table 1 can be obtained from the respective references. Table 2 shows a compendium of results generated in Brazil from 1999 to 2018 on the presence of emerging micropollutants in surface waters, notably hormones, pharmaceuticals and personal care products $^{19,35-59}$. The total number of samples and the concentrations reported above limits of quantification (LOQ) is shown. Table 2 also shows the concentration range and the classification of the samples in the three different ranges referring to the risk quotients calculated according Equation 2.

Table 2. Concentration and risks of emerging micropollutants frequently investigated in Brazilian Surface waters.

\begin{tabular}{|c|c|c|c|c|c|c|c|c|c|}
\hline Main group & Substance & $\begin{array}{c}\text { Total } \\
\text { Samples }^{\mathrm{a}}\end{array}$ & $\begin{array}{l}\text { Positivee } \\
\text { results }\end{array}$ & $\operatorname{Min}^{c}$ & $\operatorname{Max}^{c}$ & Median $^{c}$ & $\mathrm{RQ}^{\mathrm{d}} \geq 1$ & $1>\mathrm{RQ}^{\mathrm{d}} \geq 0,1$ & $\mathrm{RQ}^{\mathrm{d}}<1$ \\
\hline Hormone & $\begin{array}{c}\text { Estrone } \\
\text { 17ß-estradiol } \\
\text { Estriol } \\
17 \alpha- \\
\text { ethinylestradiol }\end{array}$ & $\begin{array}{c}278 \\
324 \\
30 \\
190\end{array}$ & $\begin{array}{c}57 \\
81 \\
9 \\
44\end{array}$ & $\begin{array}{c}0.21 \\
0.21 \\
1.5 \\
3.0\end{array}$ & $\begin{array}{c}1800 \\
13450 \\
182 \\
5900\end{array}$ & $\begin{array}{c}7.7 \\
51 \\
7.7 \\
305\end{array}$ & $\begin{array}{c}49 \\
68 \\
1 \\
44\end{array}$ & $\begin{array}{c}7 \\
13 \\
4 \\
0\end{array}$ & $\begin{array}{l}1 \\
0 \\
4 \\
0\end{array}$ \\
\hline Antibiotic & $\begin{array}{c}\text { Amoxicillin } \\
\text { Azithromycin } \\
\text { Cephalexin } \\
\text { Ciprofloxacin } \\
\text { Erythromycin } \\
\text { Norfloxacin } \\
\text { Sulfamethoxazole } \\
\text { Oxytetracycline } \\
\text { Tetracycline } \\
\text { Trimethoprim }\end{array}$ & $\begin{array}{c}10 \\
8 \\
19 \\
18 \\
8 \\
18 \\
42 \\
24 \\
18 \\
18\end{array}$ & $\begin{array}{c}5 \\
8 \\
11 \\
12 \\
4 \\
13 \\
13 \\
1 \\
7 \\
14\end{array}$ & $\begin{array}{c}1.3 \\
10 \\
2.4 \\
0.6 \\
35.3 \\
0.5 \\
1.1 \\
44 \\
11 \\
2.3\end{array}$ & $\begin{array}{c}1284 \\
313 \\
2422 \\
350 \\
1586 \\
276 \\
1529 \\
44 \\
153 \\
6376\end{array}$ & $\begin{array}{c}8.9 \\
26.2 \\
150 \\
208 \\
66 \\
114 \\
106 \\
44 \\
104 \\
150\end{array}$ & $\begin{array}{c}0 \\
5 \\
0 \\
9 \\
0 \\
9 \\
10 \\
0 \\
7 \\
9\end{array}$ & $\begin{array}{l}0 \\
3 \\
0 \\
0 \\
0 \\
1 \\
3 \\
1 \\
0 \\
5\end{array}$ & $\begin{array}{c}5 \\
0 \\
11 \\
3 \\
4 \\
3 \\
0 \\
0 \\
0 \\
0\end{array}$ \\
\hline $\begin{array}{c}\text { Anti- } \\
\text { inflammatory }\end{array}$ & $\begin{array}{l}\text { Acetylsalicylic } \\
\text { acid }\end{array}$ & 89 & 15 & 12.2 & 20960 & 2096 & 0 & 3 & 12 \\
\hline & $\begin{array}{l}\text { Diclofenac } \\
\text { Ibuprofen } \\
\text { Naproxen } \\
\text { Acetaminophen }\end{array}$ & $\begin{array}{l}196 \\
28 \\
80 \\
99\end{array}$ & $\begin{array}{l}54 \\
10 \\
28 \\
17\end{array}$ & $\begin{array}{l}0.02 \\
326 \\
0.02 \\
13.4\end{array}$ & $\begin{array}{c}8250 \\
2094 \\
21285 \\
13440\end{array}$ & $\begin{array}{c}118 \\
1659 \\
174 \\
35\end{array}$ & $\begin{array}{l}5 \\
0 \\
1 \\
1\end{array}$ & $\begin{array}{c}24 \\
10 \\
12 \\
5\end{array}$ & $\begin{array}{c}25 \\
0 \\
15 \\
11\end{array}$ \\
\hline Antidepressant & $\begin{array}{c}\text { Carbamazepine } \\
\text { Citalopram } \\
\text { Sertraline }\end{array}$ & $\begin{array}{l}33 \\
16 \\
16\end{array}$ & $\begin{array}{c}17 \\
5 \\
8\end{array}$ & $\begin{array}{c}0.12 \\
48 \\
30\end{array}$ & $\begin{array}{c}652 \\
79 \\
164\end{array}$ & $\begin{array}{l}58 \\
55 \\
62\end{array}$ & $\begin{array}{l}3 \\
0 \\
6\end{array}$ & $\begin{array}{l}6 \\
5 \\
2 \\
\end{array}$ & $\begin{array}{l}8 \\
0 \\
0\end{array}$ \\
\hline $\begin{array}{c}\text { Anthelmintic } \\
\text { Anxiolytic }\end{array}$ & $\begin{array}{l}\text { Mebendazole } \\
\text { Diazepam }\end{array}$ & $\begin{array}{l}10 \\
17\end{array}$ & $\frac{1}{12}$ & $\begin{array}{c}14 \\
0.38 \\
\end{array}$ & $\begin{array}{c}14 \\
0.71\end{array}$ & $\begin{array}{c}14 \\
0.52\end{array}$ & $\begin{array}{l}0 \\
0\end{array}$ & 0 & $\begin{array}{c}1 \\
12\end{array}$ \\
\hline Beta blocker & $\begin{array}{c}\text { Atenolol } \\
\text { Metoprolol } \\
\text { Propranolol } \\
\text { Losartan } \\
\end{array}$ & $\begin{array}{c}28 \\
19 \\
3 \\
10 \\
\end{array}$ & $\begin{array}{c}25 \\
7 \\
1 \\
3 \\
\end{array}$ & $\begin{array}{c}0.48 \\
1.3 \\
0.56 \\
12 \\
\end{array}$ & $\begin{array}{c}90 \\
28 \\
0.56 \\
32 \\
\end{array}$ & $\begin{array}{c}7.1 \\
14 \\
0.56 \\
16 \\
\end{array}$ & $\begin{array}{l}0 \\
0 \\
0 \\
0\end{array}$ & $\begin{array}{l}0 \\
0 \\
0 \\
0\end{array}$ & $\begin{array}{c}25 \\
7 \\
1 \\
3 \\
\end{array}$ \\
\hline Stimulant & Caffeine & 175 & 162 & 0.02 & 41590 & 3.1 & 6 & 13 & 143 \\
\hline $\begin{array}{l}\text { Personal care } \\
\text { product }\end{array}$ & $\begin{array}{c}\text { Triclosan } \\
\text { Galaxolide } \\
\text { Tonalide }\end{array}$ & $\begin{array}{c}151 \\
17 \\
17 \\
\end{array}$ & $\begin{array}{l}85 \\
17 \\
17 \\
\end{array}$ & $\begin{array}{l}2.2 \\
2.4 \\
2.8 \\
\end{array}$ & $\begin{array}{c}415 \\
53 \\
28 \\
\end{array}$ & $\begin{array}{l}77 \\
5.6 \\
6.3 \\
\end{array}$ & $\begin{array}{c}72 \\
0 \\
0 \\
\end{array}$ & $\begin{array}{c}13 \\
1 \\
0\end{array}$ & $\begin{array}{c}0 \\
16 \\
17 \\
\end{array}$ \\
\hline
\end{tabular}

${ }^{a}$ Total of samples investigated. ${ }^{b}$ Number of samples with concentrations reported above method LOQ. ${ }^{\text {cReported data }}$ considering only positive results. ${ }^{\mathrm{d}}$ Risk quocient $=$ MEC/PNEC.

\section{Results and discussion}

Figure 1 portrays the most frequently quantified emerging micropollutants reported in studies carried out in Brazilian surface waters between 1999 and 2018. The personal care products galaxolide and tonalide, together with the antimicrobial azithromycin, were in the top of the list. However, is important to point out that the number of samples investigated for the abovementioned substances is relatively low in comparison with data available for substances such 
caffeine and triclosan. Also, in the present work, the characteristics of the different sampling points, such as land use and potential pollution sources were not explored. Thus, aquatic systems with different degrees of anthropic impact were selected without distinction. Consequently, it is possible that the most frequently quantified substances were investigated only in a few samples as well as in more polluted aquatic systems.

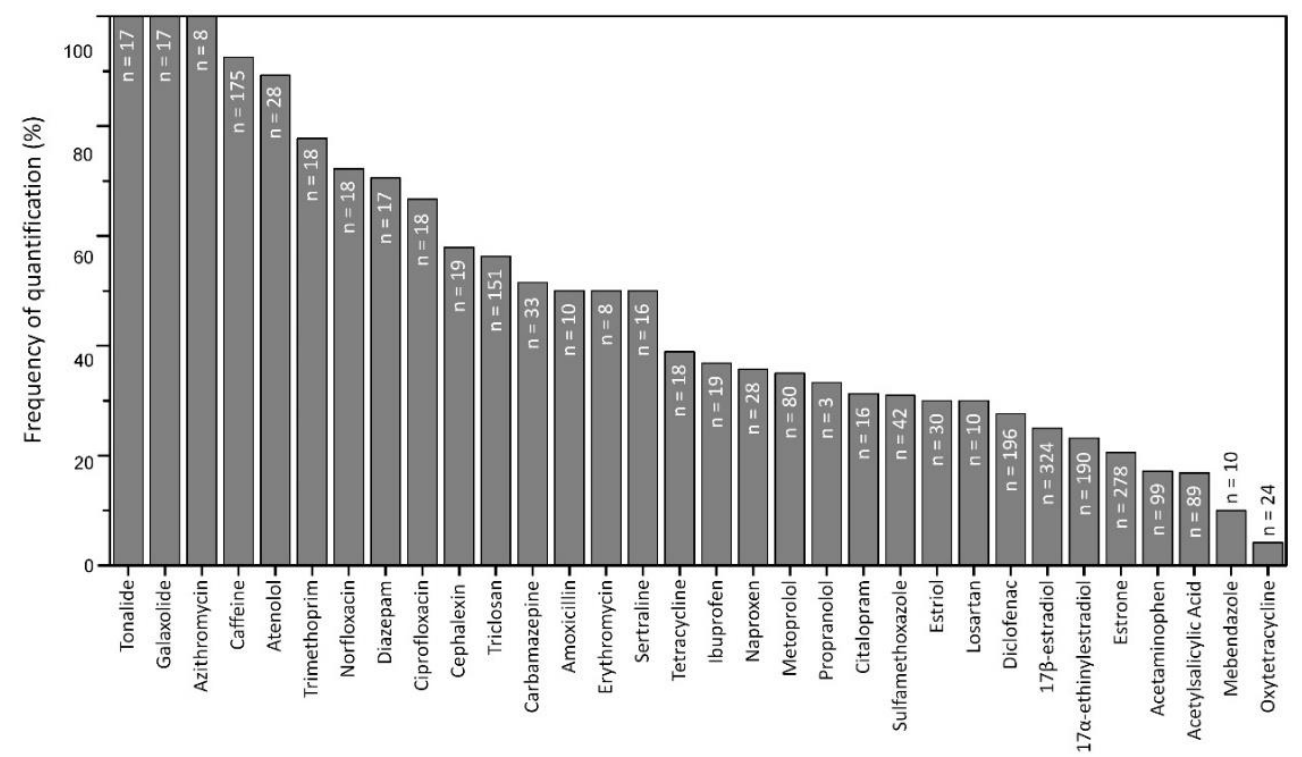

Figure 1. Percentage of samples presenting results reported above LOQ. The total of samples investigated (n) for each substance is also shown.

In Figure 1, it is also noticed that caffeine was the most frequently quantified substance $(92.6 \%)$ among the most investigated ones, followed by triclosan $(56.3 \%)$ and naproxen $(35 \%)$. The higher frequency of quantification for caffeine is in accordance with the important role of this stimulant drug as an indicator of anthropic activities, notably in Brazilian urban regions ${ }^{60-62}$.

Another important aspect is the diversity of analytical methods and techniques employed in

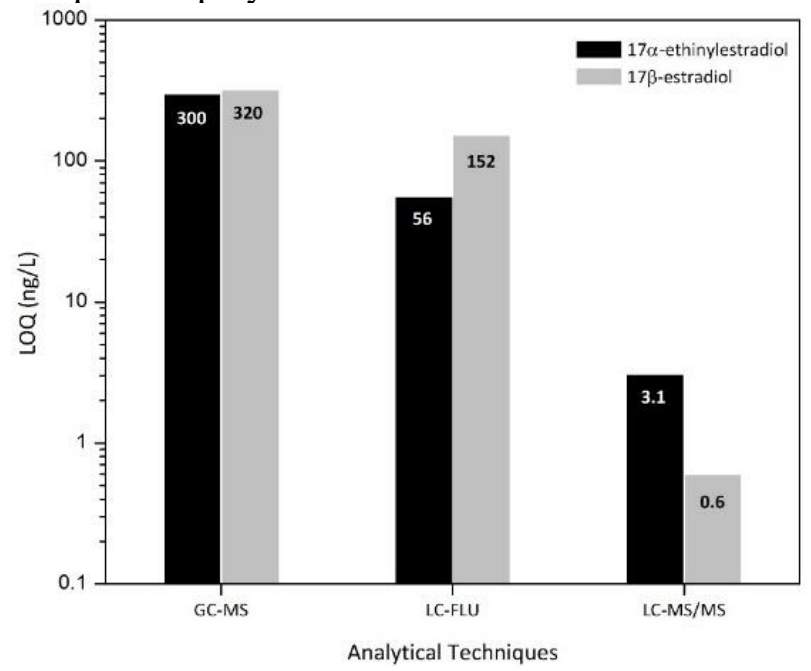

Figure 2. Method limits of quantification (LOQ) for $17 \beta$-estradiol and $17 \alpha$-ethinylestradiol obtained in different analytical systems. GC-MS: gas chromatography coupled to mass spectrometry, LC-FLU: liquid chromatography with fluorescence detector, LC-MS/MS: liquid chromatography coupled to tandem mass spectrometry ${ }^{36,45,60}$. the studies carried out in Brazil. As a result, different method LOQs are reported, which may imply in a possible underestimation of the contamination degree. For example, Figure 2 shows the evolution of method LOQs reported for the determination of $17 \alpha$-ethinylestradiol and $17 \beta-$ estradiol in surface waters from the region of Campinas (São Paulo) using different analytical techniques. 
Liquid chromatography coupled to tandem mass spectrometry (LC-MS/MS) provides higher quantification capacity, i.e., lower LOQ values, when compared to other analytical techniques. Among the 25 studies selected in the present work, $60 \%$ used LC-MS/MS systems to assess the concentrations of the target substances. Others employ liquid chromatography with fluorescence (LC-FLU) or diode array detectors (LC-DAD) as well as gas chromatography coupled to mass spectrometry (GC-MS) with or without derivatization steps. Considering the information portrayed in Figure 2, it is expected higher frequencies of quantification when data were produced using only LC-MS/MS systems.

On the other hand, one can consider that the frequency of quantification may also vary if more studies were selected covering different Brazilian regions and aquatic systems with different degrees of pollution.

Finally, it is important to mention that the studies developed in Brazil are not yet equally distributed throughout the country territory. Most of the data generated, about $44 \%$, was obtained in the state of São Paulo, followed by the states of Rio Grande do Sul (15\%), Minas Gerais (11\%) and Rio de Janeiro (11\%). These four states are among the most populous in Brazil, accounting for $45 \%$ of the country's population. The rest of the work was developed in Paraná, Mato Grosso do Sul, Federal District and Amazonas. It is interesting to note that, to the best of our knowledge, no scientific paper has yet been published on the presence of pharmaceuticals and personal care products in surface waters from Northeast Region of Brazil. This region has nine states and accounts for $28 \%$ of the Brazilian population, being the second most populous. The Southeast Region, where the states of São Paulo, Minas Gerais, Rio de Janeiro and Espírito Santo are located, is the most densely populated one.

In a recent work, Machado et al. ${ }^{42}$ aimed to perform a nationwide survey on the presence of emerging micropollutants in drinking and source waters. Although data on the presence of caffeine and atrazine were produced for drinking water samples from almost all Brazilian capitals, only surface waters from São Paulo, Minas Gerais and Rio Grande do Sul were investigated.

Figure 3 portrays the concentrations of pharmaceuticals and personal care products in Brazilian surface waters.

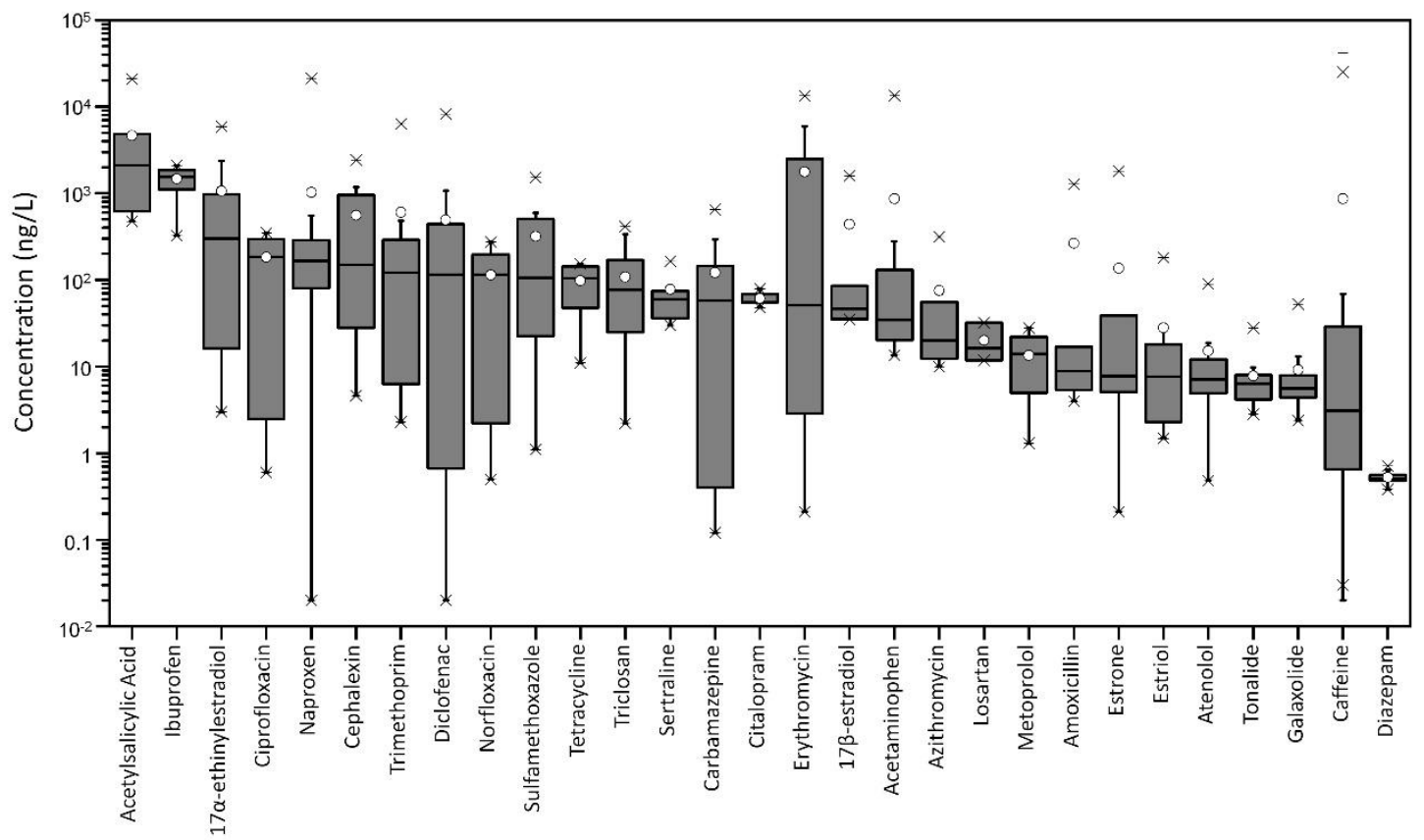

Figure 3. Box-plots of pharmaceuticals and personal care products concentrations in Brazilian surface waters. Open circles are the arithmetic means. The large box represents the 25th percentile, median, and 75th percentile; error bars indicate the 5th and 95th percentiles; $\times$-symbols represent the 1st and 99th percentiles; whiskers are the minimum and maximum values. 
Concentration ranges for the majority of the micropollutants present in Figure 3 had high amplitude, evidencing the diversity of polluted aquatic environments investigated in Brazil so far. For many substances, mean and median values are coincident or close together, whereas for the drugs amoxicillin and caffeine, for example, mean values are up to two orders of magnitude higher than medians. This behavior shows that some of the concentrations reported are exceptionally high, reflecting the influence of more polluted aquatic environments. It is interesting to note that caffeine, investigated in 175 samples and quantified in most of them, presents the highest variability of concentrations, corroborating with its role as an indicator of anthropic activities, since it differentiates aquatic environments with different degrees of pollution.

In general, the levels of pharmaceuticals and personal hygiene products in Brazilian surface waters are higher than those found in other countries, as already reported in recent literature reviews ${ }^{1,}{ }^{63}$. Higher median concentrations are noticed for acetylsalicylic acid, followed by ibuprofen and $17 \alpha$-ethinylestradiol. The first two substances have been found at high concentrations not only in Brazilian waters, but also in other countries $^{64-66}$. The same observation, however, cannot be made for $17 \alpha$-ethinylestradiol, as well as for other substances investigated in Brazil.

Quadra et al. ${ }^{63}$ evidenced that Brazilian surface waters present higher concentrations of $17 \alpha$ ethinylestradiol, 17 $\beta$-estradiol, and caffeine in comparison with other locations. In the present study, it should be noted that most of the results involving the occurrence of hormones were obtained by Machado et al. ${ }^{53}$ and Montagner et $a l .{ }^{36}$ in the Upper Iguaçu River Basin (Paraná) and in the region of Campinas (São Paulo), respectively. In both studies, mean concentrations of $17 \alpha$-ethinylestradiol and $17 \beta$-estradiol were 1916 and $3689 \mathrm{ng} / \mathrm{L}$, respectively. These values are also higher than those reported in other Brazilian regions. For example, in Minas Gerais, the average concentration of $17 \alpha$-ethinylestradiol in waters nearby the capital, Belo Horizonte, is $206 \mathrm{ng} / \mathrm{L}$, considering 15 positive data (34\% of the total) ${ }^{46,47}$. In the region of São Carlos (São Paulo), Campanha et al. ${ }^{39}$ reported an average value of $2 \mathrm{ng} / \mathrm{L}$ for $17 \beta$-estradiol in 24 positive data out of a total of $81(30 \%)$. Again, these results demonstrate the great variability of Brazilian surface waters concerning their degree of pollution, certainly influenced by sewage discharges, as pointed out earlier ${ }^{1,42,60}$.

Data for MEC portrayed in Figure 3 can be used to perform a preliminary risk assessment on the presence of pharmaceuticals and personal care products in Brazilian surface waters using Equation 2, as well as PNEC data presented in Table 1. As suggested by Komori et al. ${ }^{28}$ risk quotients (MEC/PNEC) greater than 1 imply risk while values lower than 0.1 indicate no-risk. Intermediate values indicate potential risk and, consequently, the need for further studies. Figure 4 shows individual MEC/PNEC ratios for the substances selected in the present work.

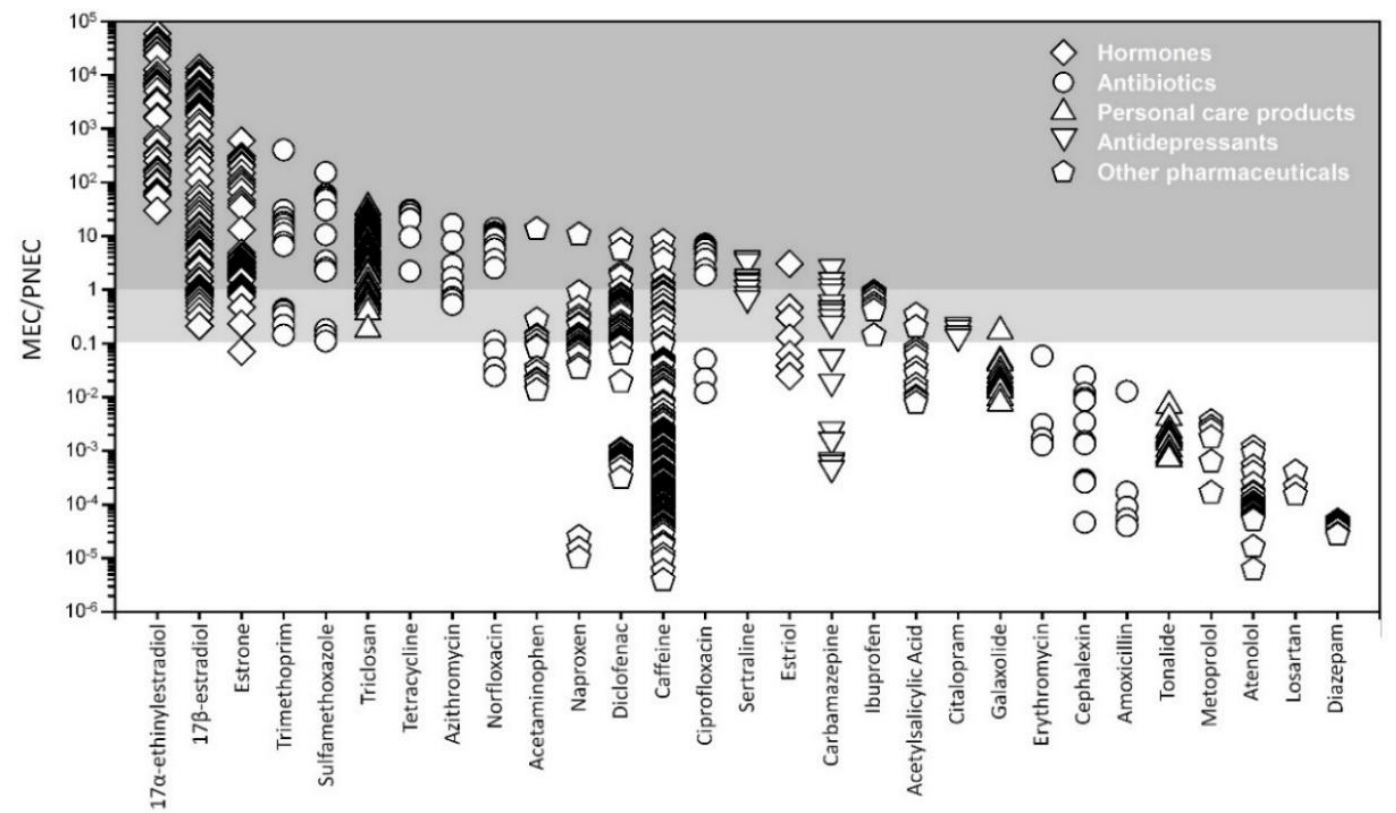

Figure 4. Environmental risk quotients of pharmaceuticals and personal care products in Brazilian waters. 
Higher risk quotients are noticed in Figure 4 for hormones and antibiotic drugs, evidencing that micropollutants of both classes should be prioritized to ensure the protection of aquatic life. Most of the risk quotients for the hormones $17 \alpha-$ ethinylestradiol, $17 \beta$-estradiol and estriol are 1000 to 10000 times greater than the first threshold (MEC/PNEC > 1), due to consequence of their high concentrations as well as to the risk that these substances may pose to aquatic biota. Triclosan should also be prioritized, since all results generated in the country so far evidence risk or possible risk. An extensive investigation on triclosan in Brazilian waters has already put this substance as a strong candidate in a priority list that must be regulated in Brazil to preserve aquatic environments ${ }^{57}$.

Non-prescribed drugs such as acetaminophen, diclofenac and naproxen, as well as the antidepressants carbamazepine and sertraline are not in the top of the rank but may also be candidates to further investigations.

Galaxolide and tonalide present the highest frequencies of quantification but are not in the top of rank due to their high PNECs which leads, therefore, to low risk quotients. These substances, however can be used as indicators of anthropic pollution, as pointed out by Glassmeyer et al. ${ }^{67}$.

Caffeine is also frequently quantified in Brazilian waters but presents low risk to aquatic biota. It is true that some risk quotients for caffeine were above the first threshold, certainly due to extremely high values reported in waters impacted by direct inputs of domestic sewage. Although most MEC/PNEC values indicate low risk for caffeine, it is important to reinforce the role of this substance as an indicator of anthropic pollution. In addition to this use approach, caffeine has recently been used to rank Brazilian surface waters presenting different levels of estrogenic activity ${ }^{61}$.

Finally, Figure 4 shows positive risk in all samples investigated for tetracycline and $17 \alpha-$ ethinylestradiol. In this case, it is important to mention that the former presented a frequency of quantification of $39 \%$ while the hormone $17 \alpha-$ ethinylestradiol could be quantified in $23 \%$ of the samples. Even so, for both substances, all samples reported with positive values (>LOQ) present risk. Thus, although such substances are obviously of concern in terms of aquatic life protection, representative results may be obtained by improving method LOQs.

\section{Conclusions}

Data on the occurrence of pharmaceuticals and personal care products in Brazilian surface waters were gathered in order to provide a preliminary snapshot on environmental contamination and risks. Although substances such as tonalide, galaxolide, atenolol and caffeine were frequently quantified, higher risks were accounted for hormones and antibiotics, as well as for triclosan, a biocide present in personal hygiene products. Key aspects including the behavior of micropollutants, as well as the influence of land use and occupation, degree of anthropic pollution, diffuse and point sources, among others, may be considered in future investigations. However, such discussions may be improved as a more uniform and broad database is available. Thus, it is evidenced the need for more studies on the diagnosis of Brazilian surface waters for the presence of several micropollutants of recent interest, legislated or not. It should be mentioned that other emerging micropollutants, such as pesticides, illicit drugs, and industrial-derived substances, were not included in this study, but they can be evaluated in future investigations using the same strategy presented here.

\section{Acknowledgements}

This work was supported by the Federal District Research Foundation (FAPDF 193.000.714/2016).

\section{References}

[1] Montagner, C. C., Vidal, C., Acayaba, R. D., Contaminantes emergentes em matrizes aquáticas do Brasil: cenário atual e aspectos analíticos, ecotoxicológicos e regulatórios, Quim. Nova 40 (9) (2017) 1094-1110. https://doi.org/10.21577/0100-4042.20170091.

[2] Focazio, M. J., Kolpin, D. W., Barnes, K. K., Furlong, E. T., Meyer, M. T., Zaugg, S. D., Barber, L. B., Thurman, M. E., A national reconnaissance for pharmaceuticals and other organic wastewater contaminants in the United States - II) Untreated drinking water sources, Sci. Total Environ. 402 (2) (2008) 201-216. https://doi.org/10.1016/j.scitotenv.2008.02.021. 
[3] Rudd, M. A., Ankley, G. T., Boxall, A. B. A., Brooks, B. W., International scientists' priorities for research on pharmaceutical and personal care products in the environment, Integr. Environ. Assess. Manag. 10 (4) (2014) 576-587. https://doi.org/10.1002/ieam.1551.

[4] Aguirre-Martínez, G. V, Owuor, M. A., Garrido-Pérez, C., Salamanca, M. J., Del Valls, T. A., Martín-Díaz, M. L., Are standard tests sensitive enough to evaluate effects of human pharmaceuticals in aquatic biota? Facing changes in research approaches when performing risk assessment of drugs, Chemosphere 120 (2015) 75-85.

https://doi.org/10.1016/j.chemosphere.2014.05.0 87.

[5] Huerta, B., Rodríguez-Mozaz, S., Barceló, D., Pharmaceuticals in biota in the aquatic environment: Analytical methods and environmental implications, Anal. Bioanal. Chem. $404 \quad$ (9) (2012) 2611-2624. https://doi.org/10.1007/s00216-012-6144-y.

[6] Bound, J. P., Voulvoulis, N., Pharmaceuticals in the aquatic environment - a comparison of risk assessment strategies, Chemosphere 56 (11) (2004) $1143-1155$. https://doi.org/10.1016/j.chemosphere.2004.05.0 10 .

[7] Cooper, E. R., Siewicki, T. C., Phillips, K., Preliminary risk assessment database and risk ranking of pharmaceuticals in the environment, Sci. Total Environ. 398 (1) (2008) 26-33. https://doi.org/10.1016/j.scitotenv.2008.02.061.

[8] Roos, V., Gunnarsson, L., Fick, J., Larsson, D. G. J., Rudén, C., Prioritising pharmaceuticals for environmental risk assessment: Towards adequate and feasible first-tier selection, Sci. Total Environ. 421-422 (2012) 102-110. https://doi.org/10.1016/j.scitotenv.2012.01.039.

[9] Cunningham, V. L., Binks, S. P., Olson, M. J., Human health risk assessment from the presence of human pharmaceuticals in the aquatic environment, Regul. Toxicol. Pharmacol. 53 (1) (2009) 39-45. https://doi.org/10.1016/j.yrtph.2008.10.006.

[10] Pereira, A. M. P. T., Silva, L. J. G., Lino, C, M., Meisel, L. M., Pena, A., A critical evaluation of different parameters for estimating pharmaceutical exposure seeking an improved environmental risk assessment, Sci. Total Environ. 603-604 (2017) 226-236. https://doi.org/10.1016/j.scitotenv.2017.06.022.

[11] De Bruijn, J., Hansen, B. G., Johansson, S., Luotamo, M., Munn, S. J., Musset, C., Olsen, S. I., Olsson, H., Paya-Perez, A. B., Pedersen, F., Rasmussen, K., Sokull-Kluttgen, B., Technical Guidance Document on Risk Assessment. Part II: Environmental Risk Assessment, 2003. Available from:

<https://echa.europa.eu/documents/10162/16960 216/tgdpart2_2ed_en.pdf>.

[12] European Chemicals Agency. Guidance on Information Requirements and Chemical Safety Assessment. Chapter R.10: Characterisation of dose [concentration]-response for environment, 2008. Available from: <https://echa.europa.eu/documents/10162/13632/ information_requirements_r10_en.pdf/bb902be7a503-4ab7-9036-d866b8ddce69> .

[13] Sanderson, H., Johnson, D. J., Wilson, C. J., Brain, R. A., Solomon, K. R., Probabilistic hazard assessment of environmentally occurring pharmaceuticals toxicity to fish, daphnids and algae by ECOSAR screening, Toxicol. Lett. 144 (3) (2003) 383-395. https://doi.org/10.1016/S0378-4274(03)00257-1.

[14] Turkdogan, F. I., Yetilmezsoy, K., Appraisal of potential environmental risks associated with human antibiotic consumption in Turkey, J. Hazard. Mater. 166 (1) (2009) 297-308. https://doi.org/10.1016/j.jhazmat.2008.11.012.

[15] Jones, O. A. H., Voulvoulis, N., Lester, J. N., Aquatic environmental assessment of the top 25 English prescription pharmaceuticals, Water Res. $36 \quad$ (20) (2002) 5013-5022. https://doi.org/10.1016/S0043-1354(02)00227-0.

[16] Stuer-Lauridsen, F., Birkved, M., Hansen, L.P., Lützhøft, H. C. H., Halling-Sørensen, B., Environmental risk assessment of human pharmaceuticals in Denmark after normal therapeutic use, Chemosphere 40 (7) (2000) 783$793 . \quad$ https://doi.org/10.1016/S00456535(99)00453-1. 
[17] de Souza, S. M. L., de Vasconcelos, E. C., Dziedzic, M., de Oliveira, C. M. R., Environmental risk assessment of antibiotics: An intensive care unit analysis, Chemosphere 77 (7) (2009) 962-967. https://doi.org/10.1016/j.chemosphere.2009.08.0 10.

[18] Baldoni, A. D. O., Guidoni, C. M., Pereira, L. R. L., A farmacoepidemiologia no Brasil: estado da arte da produção científica, Rev. Univ. Vale Rio Verde 9 (1) (2011) 78-88. https://doi.org/10.5892/RUVRV.91.7888.

[19] Locatelli, M. A. F., Sodré, F. F., Jardim, W. F., Determination of antibiotics in Brazilian surface waters using liquid chromatographyelectrospray tandem mass spectrometry, Arch Environ. Contam. Toxicol. 60 (3) (2011) 385-393. https://doi.org/10.1007/s00244-010-9550-1.

[20] Harada, A., Komori, K., Nakada, N., Kitamura, K., Suzuki, Y., Biological effects of PPCPs on aquatic lives and evaluation of river waters affected by different wastewater treatment levels, Water Sci. Technol. 58 (8) (2008) 15411546. https://doi.org/10.2166/wst.2008.742.

[21] Yang, L. -H., Ying, G. -G., Su, H. -C., Stauber, J. L., Adams, M. S., Binet, M. T., Growth-inhibiting effects of 12 antibacterial agents and their mixtures on the freshwater microalga Pseudokirchneriella subcapitata, Environ. Toxicol. Chem. 27 (5) (2008) 12011208. https://doi.org/10.1897/07-471.1.

[22] Ferrari, B., Paxéus, N., Lo Giudice, R., Pollio, A., Garric, J., Ecotoxicological impact of pharmaceuticals found in treated wastewaters: study of carbamazepine, clofibric acid, and diclofenac, Ecotoxicol. Environ. Saf. 55 (3) (2003) 359-370. https://doi.org/10.1016/S01476513(02)00082-9.

[23] Gheorghe, S., Petre, J., Lucaciu, I., Stoica, C., Nita-Lazar, M., Risk screening of pharmaceutical compounds in Romanian aquatic environment, Environ. Monit. Assess. 188 (6) (2016) 379. https://doi.org/10.1007/s10661-016-5375-3.

[24] Mukai, D., Matsuda, N., Yoshioka, Y., Sato, M., Yamasaki, T., Potential anthelmintics: polyphenols from the tea plant Camellia sinensis L. are lethally toxic to Caenorhabditis elegans, J.
Nat. Med. 62 (2) (2008) 155-159. https://doi.org/10.1007/s11418-007-0201-4.

[25] Young, W. F., Whitehouse, P., Johnson, I., Sorokin, N., Proposed Predicted-no-effectconcentrations (PNECs) for Natural and Synthetic Steroid Oestrogens in Surface Waters, Bristol, Environmental Agency, 2002.

[26] Caldwell, D. J., Mastrocco, F., Anderson, P. D., Länge, R., Sumpter, J. P., Predicted-no-effect concentrations for the steroid estrogens estrone, $17 \beta$-estradiol, estriol, and $17 \alpha$-ethinylestradiol, Environ. Toxicol. Chem. 31 (6) (2012) 13961406. https://doi.org/10.1002/etc.1825.

[27] Isidori, M., Lavorgna, M., Nardelli, A., Pascarella, L., Parrella, A., Toxic and genotoxic evaluation of six antibiotics on non-target organisms, Sci. Total Environ. 346 (1) (2005) 8798.

https://doi.org/10.1016/j.scitotenv.2004.11.017.

[28] Komori, K., Suzuki, Y., Minamiyama, M., Harada, A., Occurrence of selected pharmaceuticals in river water in Japan and assessment of their environmental risk, Environ. Monit. Assess. 185 (6) (2013) 4529-4536. https://doi.org/10.1007/s10661-012-2886-4.

[29] Silva, L. J. G., Pereira, A. M. P. T., Meisel, L. M., Lino, C. M., Pena, A., A one-year followup analysis of antidepressants in Portuguese wastewaters: Occurrence and fate, seasonal influence, and risk assessment, Sci. Total Environ. $490 \quad$ (2014) 279-287. https://doi.org/10.1016/j.scitotenv.2014.04.131.

[30] Christensen, A.M., Faaborg-Andersen, S., Ingerslev, F., Baun, A., Mixture and singlesubstance toxicity of selective serotonin reuptake inhibitors toward algae and crustaceans, Environ. Toxicol. Chem. 26 (1) (2007) 85. https://doi.org/10.1897/06-219R.1.

[31] Cleuvers, M., Initial risk assessment for three $\beta$-blockers found in the aquatic environment, Chemosphere 59 (2) (2005) 199-205. https://doi.org/10.1016/j.chemosphere.2004.11.0 90.

[32] Godoy, A. A., Kummrow, F., Pamplin, P. A. Z., Ecotoxicological evaluation of propranolol hydrochloride and losartan potassium to Lemna 
minor L. (1753) individually and in binary mixtures, Ecotoxicology 24 (5) (2015) 11121123. https://doi.org/10.1007/s10646-015-14553.

[33] Rorije, E., Aldenberg, T., Peijnenburg, W., Read-across estimates of aquatic toxicity for selected fragrances, Altern. Lab. Anim. 41 (1) (2013) 77-90, Available from: <http://www.atla.org.uk/read-across-estimatesof-aquatic-toxicity-for-selected-fragrances/>.

[34] National Industrial Chemicals, Notification and Assessment Scheme, Environment Tier II: Assessment for Tonalide and Related Polycyclic Musks, 2017. Available from: $<$ https://www.nicnas.gov.au/chemicalinformation/imap-assessments/imapassessments/tier-ii-environmentassessments/environment-tier-ii-assessment-fortonalide-and-related-polycyclic-musks>.

[35] Lopes, L. G., Marchi, M. R. R., Souza, J. B. G., Moura, J. A., Lorenzon, C. S., Cruz, C., Amaral, L. A., Estrogênios em águas naturais e tratadas da região de Jaboticabal - São Paulo, Quim. Nova 33 (2010) 639-643. https://doi.org/10.1590/S0100-

40422010000300029.

[36] Montagner, C. C., Jardim, W. F., Spatial and seasonal variations of pharmaceuticals and endocrine disruptors in the Atibaia River, São Paulo State (Brazil), J. Braz. Chem. Soc. 22 (8) (2011) 1452-1462. https://doi.org/10.1590/S0103-

50532011000800008 .

[37] Jardim, W. F. Montagner, C. C., Pescara, I. C., Umbuzeiro, G. A., Di Dea Bergamasco, A. M., Eldridge, M. L., Sodré, F. F., An integrated approach to evaluate emerging contaminants in drinking water. Sep. Purif. Technol. 84 (2012) 38. https://doi.org/10.1016/j.seppur.2011.06.020.

[38] Di Dea Bergamasco, A. M., Eldridge, M., Sanseverino, J., Sodré, F. F., Montagner, C. C., Pescara, I. C., Jardim, W. F., Umbuzeiro, G. A., Bioluminescent yeast estrogen assay (BLYES) as a sensitive tool to monitor surface and drinking water for estrogenicity, J. Environ. Monit. 13 (11) (2011)

3288-3293. https://doi.org/10.1039/c1em10464k.
[39] Campanha, M. B., Awan, A. T., de Sousa, D. N. R., Grosseli, G. M., Mozeto, A. A., Fadini, P. S., A 3-year study on occurrence of emerging contaminants in an urban stream of São Paulo State of Southeast Brazil, Environ. Sci. Pollut. Res. $22 \quad$ (10) (2015) 7936-7947. https://doi.org/10.1007/s11356-014-3929-x.

[40] Santos, M. M. dos, Brehm, F. de A., Filippe, T. C., Knapik, H. G., Azevedo, J. C. R. de, Occurrence and risk assessment of parabens and triclosan in surface waters of southern Brazil: a problem of emerging compounds in an emerging country, RBRH. 21 (2016) 603-617. https://doi.org/10.1590/2318-0331.011616018.

[41] Pereira, C. D. S. Maranho, L. A., Cortez, F. S., Pusceddu, F. H., Santos, A. R., Ribeiro, D. A., Cesar, A., Guimarães, L. L., Occurrence of pharmaceuticals and cocaine in a Brazilian coastal zone, Sci. Total. Environ. 548 (2016) 148-154. https://doi.org/10.1016/j.scitotenv.2016.01.051.

[42] Machado, K. C., Grassi, M. T., Vidal, C., Pescara, I. C., Jardim, W. F., Fernandes, A. N., Sodré, F. F., Almeida, F. V., Santana, J. S., Canela, M. C., Nunes, C. R. O., Bichinho, K. M., Severo, F. J. R., A preliminary nationwide survey of the presence of emerging contaminants in drinking and source waters in Brazil, Sci. Total. Environ. $\quad 572 \quad$ (2016) 138-146. https://doi.org/10.1016/j.scitotenv.2016.07.210.

[43] Sodré, F. F., Santana, J. S., Sampaio, T. R., Brandão, C. C. S., Seasonal and spatial distribution of caffeine, atrazine, atenolol and DEET in surface and drinking waters from the Brazilian Federal District, J. Braz. Chem. Soc. (2018). https://doi.org/10.21577/01035053.20180061.

[44] Stumpf, M., Ternes, T. A., Wilken, R. -D., Rodrigues, S. V., Baumann, W., Polar drug residues in sewage and natural waters in the state of Rio de Janeiro, Brazil, Sci. Total Environ. 225 (1) (1999) 135-141. https://doi.org/10.1016/S0048-9697(98)00339-8.

[45] Sodré, F. F., Montagner, C. C., Locatelli, M. A. F., Jardim, W. F., Ocorrência de Interferentes endócrinos e produtos farmacêuticos em águas superficiais da região de Campinas (SP, Brasil), J. Braz. Soc. Ecotoxicol. 2 (2) (2007) 187-196. https://doi.org/10.5132/jbse.2007.02.012. 
[46] Moreira, D. S., Aquino, S. F., Afonso, R. J. C. F., Santos, E. P. P. C., de Pádua, V. L., Occurrence of endocrine disrupting compounds in water sources of Belo Horizonte Metropolitan Area, Brazil, Environ. Technol. 30 (10) (2009) 1041-1049.

https://doi.org/10.1080/09593330903052830.

[47] Moreira, M., Aquino, S., Coutrim, M., Silva, J., Afonso, R., Determination of endocrinedisrupting compounds in waters from Rio das Velhas, Brazil, by liquid chromatography/high resolution mass spectrometry (ESI-LC-ITTOF/MS), Environ. Technol. 32 (12) (2011) 1409-1417.

https://doi.org/10.1080/09593330.2010.537829.

[48] Cordeiro, D., da Rocha, G. C., Onaka, E. M., Cappelini, L. T. D., Pereira, R. de O., Pacces, V. H. P., Vieira, E. M., HPLC determination of hormones in São José do Rio Preto municipal dam, São Paulo, Brazil, J. Liq. Chromatogr. Relat. Technol. $35 \quad$ (19) (2012) 2685-2695. https://doi.org/10.1080/10826076.2011.637275.

[49] Wilde, M. L., Kümmerer, K., Martins, A. F., Multivariate optimization of analytical methodology and a first attempt to an environmental risk assessment of $\beta$-blockers in hospital wastewater, J. Braz. Chem. Soc. 23 (2012) $1732-1740$.

https://doi.org/10.1590/S0103-

50532012005000035 .

[50] Caldas, S. S., Bolzan, C. M., Guilherme, J. R., Silveira, M. A. K., Escarrone, A. L. V., Primel, E. G., Determination of pharmaceuticals, personal care products, and pesticides in surface and treated waters: method development and survey, Environ. Sci. Pollut. Res. 20 (8) (2013) 5855-5863. https://doi.org/10.1007/s11356-013-1650-9.

[51] Jank, L., Hoff, R. B., da Costa, F. J., Pizzolato, T. M., Simultaneous determination of eight antibiotics from distinct classes in surface and wastewater samples by solid-phase extraction and high-performance liquid chromatographyelectrospray ionisation mass spectrometry, Int. J. Environ. Anal. Chem. 94 (10) (2014) 1013-1037. https://doi.org/10.1080/03067319.2014.914184.

[52] de Sousa, D. N. R., Mozeto, A. A., Carneiro, R. L., Fadini, P. S., Electrical conductivity and emerging contaminant as markers of surface freshwater contamination by wastewater, Sci. Total Environ. 484 (2014) 19-26. https://doi.org/10.1016/j.scitotenv.2014.02.135.

[53] Machado, K. S., Cardoso, F. D., Azevedo, J. C. R., Braga, C. B., Occurrence of female sexual hormones in the Iguazu river basin, Curitiba, Paraná State, Brazil, Acta Sci. Technol. 36 (3) (2014) $421-427$. https://doi.org/10.4025/actascitechnol.v36i3.1847 7.

[54] Lopes, V. S. A., Riente, R. R., da Silva, A. A., Torquilho, D. F., da Silva Carreira, R., da Costa Marques, M. R., Development of a solid-phase extraction system modified for preconcentration of emerging contaminants in large sample volumes from rivers of the lagoon system in the city of Rio de Janeiro, Brazil, Mar. Pollut. Bull. $110 \quad$ (1) (2016) 572-577. https://doi.org/10.1016/j.marpolbul.2016.05.059.

[55] Monteiro, M. A., Spisso, B. F., Santos, J. R. M. P, Costa, R. P., Ferreira, R. G., Pereira, M. U., Miranda, T. S., Andrade, B. R. G., D' Avila, L. A., Occurrence of antimicrobials in river water samples from rural region of the State of Rio de Janeiro, Brazil, J. Environ. Prot. 7 (2) (2016) 230341. https://doi.org/10.4236/jep.2016.72020.

[56] Américo-Pinheiro, J. H. P., Isique, W. D., Torres, N. H., Machado, A. A., Carvalho, S. L. de, Valério Filho, W. V., Ferreira, L. R. R., Ocorrência de diclofenaco e naproxeno em água superficial no município de Três Lagoas (MS) e a influência da temperatura da água na detecção desses anti-inflamatórios, Eng. Sanit. Ambient. 22 (2017) 429-435. https://doi.org/10.1590/s141341522017128719.

[57] Montagner, C. C., Jardim, W. F., der Ohe, P. C., Umbuzeiro, G. A., Occurrence and potential risk of triclosan in freshwaters of São Paulo, Brazil---the need for regulatory actions, Environ. Sci. Pollut. Res. 21 (3) (2014) 1850-1858. https://doi.org/10.1007/s11356-013-2063-5.

[58] Thomas, K. V, da Silva, F. M. A., Langford, K. H., de Souza, A. D. L., Nizzeto, L., Waichman, A. V., Screening for Selected Human Pharmaceuticals and Cocaine in the Urban Streams of Manaus, Amazonas, Brazil, J. Am. Water Resour. Assoc. 50 (2) (2014), 302-308. https://doi.org/10.1111/jawr.12164. 
[59] Sodré, F. F., Pescara, I. C., Montagner, C. C., Jardim, W. F., Assessing selected estrogens and xenoestrogens in Brazilian surface waters by liquid chromatography-tandem mass spectrometry, Microchem J. 96 (1) (2010) 92-98. https://doi.org/10.1016/j.microc.2010.02.012.

[60] Sodré, F. F., Locatelli, M. A. F., Jardim, W. F., Occurrence of emerging contaminants in Brazilian drinking waters: A sewage-to-tap issue, Water Air Soil Pollut. 206 (1-4) (2010) 57-67. https://doi.org/10.1007/s11270-009-0086-9.

[61] Montagner, C. C., Umbuzeiro, G. A., Pasquini, C., Jardim, W. F., Caffeine as an indicator of estrogenic activity in source water, Environ. Sci. Process. Impacts 16 (8) (2014) 1866-1869.

https://doi.org/10.1039/C4EM00058G.

[62] Ferreira, A. P., Caffeine as an environmental indicator for assessing urban aquatic ecosystems, Cad. Saude Publica 21 (2005) 1884-1892. https://doi.org/10.1590/S0102-

311X2005000600038.

[63] Quadra, G. R., de Souza, H., Costa, R. dos S., Fernandez, M. A. dos S., Do pharmaceuticals reach and affect the aquatic ecosystems in Brazil? A critical review of current studies in a developing country, Environ. Sci. Pollut. Res. 24 (2) (2017) 1200-1218. https://doi.org/10.1007/s11356-0167789-4.

[64] Liu, J. -L., Wong, M. -H., Pharmaceuticals and personal care products (PPCPs): A review on environmental contamination in China, Environ. Int. $\quad 59 \quad$ (2013) 208-224. https://doi.org/10.1016/j.envint.2013.06.012.

[65] Gumbi, B. P., Moodley, B., Birungi, G., Ndungu, P. G., Detection and quantification of acidic drug residues in South African surface water using gas chromatography-mass spectrometry, Chemosphere 168 (2017) 10421050.

https://doi.org/10.1016/j.chemosphere.2016.10.1 05.

[66] Nannou, C. I., Kosma, C. I., Albanis, T. A., Occurrence of pharmaceuticals in surface waters: analytical method development and environmental risk assessment, Int. J. Environ.
Anal. Chem. 95 (13) (2015) 1242-1262. https://doi.org/10.1080/03067319.2015.1085520.

[67] Glassmeyer, S. T. Furlong, E. T., Kolpin, D. W., Cahill, J. D., Zaugg, S. D., Werner, S. L., Meyer, M. T., Kryak, D. D., Transport of chemical and microbial compounds from known wastewater discharges: potential for use as indicators of human fecal contamination, Environ. Sci. Technol. 39 (2005) 5157-5169. https://doi.org/10.1021/es048120k. 